\title{
Early Clinical Exposure Based Group Counseling Practice Model to Increase Counselor Candidate Competence In Group Counseling Services
}

\author{
T. Sutanti \& Irvan Budhi Handaka \\ Universitas Ahmad Dahlan, Yogyakarta, Indonesia
}

\author{
Suwarjo \& Budi Astuti \\ Universitas Negeri Yogyakarta, Yogyakarta, Indonesia
}

\begin{abstract}
This study aims to examine various literatures on early clinical exposure method to improve the competence of counselor candidate in providing group counseling service. The method used is by literature study. The results showed that practical model of group counseling based on early clinical exposure is a method of practice learning that introduces the world of work from an early study by presenting a factorial model that is factual, able to introduce problems, original counselees and situations that are real in counseling. ECE is also useful to develop attachment, love and responsibility of the counselor candidate to his profession early on.
\end{abstract}

\section{Keywords: counselling service, clinical exposure, counsellor}

\section{INTRODUCTION}

Globalization has a good and bad impact on society. The good impact is the opening of various information needed in life, in the field of technology, social, economic and culture. On the other hand, the bad impact is the incidence of public trouble due to such openness, such as crime, juvenile delinquency such as drugs, capitalism, socialism and other social trouble. Education has a close relationship with globalization. As the era of globalization grows, education must be balance and developed in order to survive the exposure of globalization. To achieve the success of education in Indonesia an optimal role of educators is requires, including guidance and counseling teachers in schools.

Professional school counselors need to take an active role in initiating, facilitating and promoting character education program in the school curriculum. The Professional school counselors, as a part of the school community and as highly resourceful person, takes an active role by working cooperatively with the teacher and administrators in providing character education in the school as an integral part of the school curriculum and activities (ASCA, 2011).

Therefore, school counselors who are considered as an expert must understand their big task and are able to work cooperatively with the teacher and administrators in order to develop students' character. Guidance and counseling has several types of service that can be used to optimize students' character development and solve their problems. It can be categorized into two services, i.e. individual counseling service and group counseling service. The purpose of group counseling is to optimize the members' development and assist them in solving their problem.
In fact, based on the result of the study done by Sutanti (2014) about the implementation of group counseling to the gifted students in two schools in Yogyakarta, it was found that there were several obstacles that lead to the ineffectiveness of group counseling in SMAN Yogyakarta. This is found within both the school counselors as operator, the service itself and the facility of the services. Besides, group counseling applied to gifted students was still done in the same way with regular students, whereas, they should have been handled by doing an appropriate group counseling to optimize their gifts and intelligence.

The development of counselors' knowledge and ability in doing guidance and counseling can be done through the counselor candidates' competence development in theoretical and practical framework earlier. In this case, universities in which guidance and counseling program exist, are responsible for developing school counselors' ability by giving them knowledge and ability through guidance and counseling practice activities.

Early Clinical Exposure (ECE) is a learning method that gives students opportunities to learn factually. It is a learning process where students are introduced to a clinical condition according to the material that is being learned. In guidance and counseling learning settings, what is so called as clinical is in regular and inclusive school scope, the social institution such as drug rehabilitation and social environment such as disaster victims. In early exposure, students are expected to be able to reflect the obtained theory and identify the fields' conditions that need relevant guidance and counseling service earlier. Therefore, ECE is a learning method that is considered as effective to be applied in group counseling lecture so that the students of guidance and counseling program have abilities in doing services according to society' needs. Based on the description above, the writer is interested in studying early clinical exposure based-group counseling model towards Guidance and Counseling Program students. The study in this article is a part of study done by the writer in developing ECE based-group counseling practice model for Guidance and Counseling program students.

\section{METHOD}

This study aims to examine various literature on early clinical exposure method to improve the competence of counselor candidates in providing group counseling service. 
The method used is by literature study. Data collection techniques used are documentation studies in the form of relevant journals and books. Data analysis techniques used are through steps of data reduction, data presentation and conclusion. Milles Huberman (in Sugiyono, 2014: 91).

\section{RESULTS AND DISCUSSION}

The results of this study describe the contents of various theories from relevant journals and books about early clinical exposure methods to improve the competence of counselors in providing group counseling services.

\subsection{Group Counseling}

Guidance and Counseling has some services in individual and group settings. One of them is group counseling. This service has an advantage where the members of the group get opportunities to solve their problems through interaction with other members helped by a counselor. Corey (2012: 28) stated, "group counseling has preventive as well as remedial aims". Generally, the counseling group has specific focus which maybe educational, career, social and personal. Group works emphasizes interpersonal communication of conscious thought, feelings, and behavior within here and now period. Counseling group are often problem oriented, and the members largely determine their content and aims."

There are some other advantages of group counseling. According to Jacob (2006: 19), for some people, group counseling is better than individual ones since group members need others' suggestion, they also learn to listen and respect rather than only speak. In teenagers' environment, group counseling is better that the individual counseling since they are usually happier to talk with other teenagers than with adults. Group counseling helps someone to listen, respect, share, and empathy of other members' problems, expresses idea, develops awareness, learn about confidence, develop social skill, and responsibility. It also helps them change negative behavior and find the wise solutions of their problems or others'.

Counselors must master group counseling as a service in guidance and counseling area. The implantation of counselor' ability in doing counseling service is started in the college through group counseling practice lecture. Therefore, group counseling practice should be done with factual learning process so that the students are able to learn about group counseling since early stage. In this study, the focus of developing ECE based-group counseling practice model for counselor candidates not only focuses on students problem in school, but also critical problem that needs group counseling in society.

\subsection{How to teach Group counseling to the Counselor Candidate?}

In order to obtain the purpose of group counseling, as counselors, they are required to have some counseling basic skills.

Jacob (2006: 126) explained that there were some basic counseling skills that must be mastered by a group leader or counselor in group counseling. Those are active listening, reflection, clarifying and questioning, summarizing, linking, minilecturing and information giving, encouraging and supporting, tone setting, modeling and self-disclosure, use of eyes, use of voice, use of the leader's energy, identifying allies, and multicultural understanding. While (Suwarjo et al. (2012)) describes some basic skills that should be mastered by counselor candidates as follows; active listening, reflection, feeling, counselee' experiences, clarifying and questioning, empathy, genuine behavior ability, confront ability, problem solving, and concluding conversation.

Based on several counseling basic skill that had been described above, it can be concluded that to be professional counselors in doing group counseling, they should, at least master some counseling basic skill used in beginning, middle, or ending stage. Counselor skill strengthening can be started early in counselor candidate educational stage.

3.3 How to teach ECE based-Group Counseling Practice to the students as counselor candidate?

The counselors' knowledge and skill strengthening in doing group counseling should be begun early in guidance and counseling program' lectures. It can be done through giving practical subject. Therefore, group counseling practice lecture should be designed based on factual condition in reality.

According to Mafinejad et al (2016: 195), "early clinical exposure (ECE) is a way to integrate the knowledge of basic and clinical sciences and the psychosocial aspects of medical practice". It is a method that gives students opportunity to learn factually. It is a learning process where students are introduced to clinical condition according to the material being learnt. In guidance and counseling settings, what is so called as clinical is in regular and inclusive school scope, social institution such as drug addicts' rehabilitation institution, and society' environment such as disaster victims.

Motilal (2014: 3) stated that "Education system across the world now emphasize early clinical exposure towards horizontal and vertical integration and contextual learning in the local settings". It can be interpreted that educational systems around the world nowadays underline ECE towards horizontal and vertical integration through contextual local setting learning process. BitaAfra, et al (2015) stated that, "Early exposure of medical students to clinical experiences will enhance their professional socialization process and will provide effective learning along with understanding. Early exposure to a clinical medicine program helps new students to cope with tension and job stress and improves their awareness of their profession."

That statement describes that ECE method is able to improve students' professional socialization process and will bring them a learning process that is effectively understandable. It helps them reduce their job stress and improves their profession awareness.

Rawekar et al. (2016) stated that, "Early clinical exposure exposing the students to the varied patient load does not pose a problem in Indian setting. In fact, it can have an added advantage to the students for a firsthand experience and thus leading to deep learning." Based on the statement above, it can be interpreted that ECE explains to the 
medical students about patients' disease diversity. This method does not cause problems in India. Moreover, it gave students additional advantage in a form of direct experience so that it led to deep learning.

The result of the study conducted by BitaAfra et.al (2015) about experimental group of medical students who was given ECE method, shows awareness of their job' role and responsibility, specific awareness, patients' problems sensitivity, medical limitedness understanding, educational material interests, future workplace familiarity, and profession confidence.

Early Clinical Exposure learning method provides many benefits for medical students. Sawant and ShaheenRizvi (2015) stated that Early clinical exposure (ECE) will help students to develop a professional identity, increase motivation to learn, ensure well integrated knowledge of the basic sciences so as to retain knowledge better and even consider career options earlier. ECE also promotes selfdirected learning and analytical skills in students.

Tayade (2015) claimed that early clinical exposure was a better learning methodology than traditional teaching for students in Indian Scenario. Esfehani et al. (2012) said that ECE was perceived positively by students and could provide a framework for integration of basic sciences with clinical subjects for the medical students. ECE can be an important and efficient factor in improving the motivation and can be a great help in the recall of knowledge in medical students.

Based on this study, ECE method is considered as important to be developed in practical learning for counselor candidates. Through this method, they are expected to be able to reflect the obtained theory and understand the condition in reality earlier. Moreover, it is expected that they will gain case variety experienced by counselee in the various settings that need relevant guidance and counseling service. hence, ECE method is considered as effective to be applied in group counseling practice lecture so they are capable and skillful in doing appropriate guidance and counseling service for society' need.

ECE method application in group counseling practice learning for counselor candidates can be done by noticing these following steps: 1) Before taking the group counseling practice subject, they must complete the theory of group counseling subject. 2) In the beginning of group counseling practice subject, they are invited to do an observation to regular and inclusive school, and institutions that need group counseling service (e.g. drug addicts' rehabilitation institution and disaster counseling institution) under the guidance and supervision of the lecturers. 3) They do an assessment about the problem found from the observation and those who need group counseling service under the guidance and supervision of the lecturers. 4) They are taught how to make a group counseling service plan and practice it under the lecturer' guidance and supervision. 5) They do group counseling service in the laboratory by facing real counselee and problems based on the result of the assessment under the lecturers' guidance and supervision. In this activity, they learn how to apply their counseling skill, problem solving skill, counselee handling skill, and learn to be responsible for their profession as counselor. 6) They are taught how to make the group counseling report and practice it under the supervision and guidance of the lecturers.

The uniqueness of ECE method in group counseling practice learning for counselor candidates is in the introduction of reality during practice learning earlier. Through practical learning that brings real situation and counselee, they are able to learn factually, not only learn theoretically. Recently, in a part of group counseling practice learning, they are often taught by using manipulative problems. They are asked to make up a problem and the problem solving steps, then, their classmates practice it. Manipulative model of group counseling learning leads them to cultural shock such as anxious, panic and not confident when facing real counselee with real problems.

\section{CONCLUSION}

ECE based- Group counseling practice model can be an alternative learning model for the students as counselor candidates. This model teaches them to recognize the condition of their workplace earlier and factually so that they will be familiar with their profession and workplace. ECEbased practice teaches them to be responsible for their duty, develop awareness and empathy to the counselee, and develop counselors' job readiness. Based on that description, it is predicted that it will be able to improve their capability in doing group counseling service. It is suggested for group counseling subjects' lecturers to be able to give practical learning model so that the counselor candidates will be familiar with their job and profession, able to learn factually about group counseling, and able to strengthen their counseling abilities as early as possible.

\section{REFERENCES}

[1] ASCA.2011 The Profesional Counselor and Character Education. 2011.https://www.schoolcounselor.org/asca/media/asca/home/position\% 20statements/PS_CharacterEducation.

[2] Bita,Afra., MahastiAlizadeh., SiminTaghavi., HosseinJabbariBayrami., JavaherYari. (2015). The Impact of Early Clinical Exposure on the Knowledge and Attitude of Basic Sciences Medical Students at Tabriz University of Medical Sciences. Journal Rev Dev Med Educ, 4 (1),5560.

[3] Corey, Gerald. 2012. Theory and Practice of Group Counseling.Eighth edition. USA: Broks/Cole Thompson.

[4] Esfehani at al (2012) The Effect of Early Clinical Exposure on Learning Motivation of Medical Students. Future of medical education jurnal 2;2 mums.ac.ir/j-fmej

[5] Jacob, Ed. 2006. Group Counseling Strategies and Skill.Fiveth edition USA: Broks/Cole Thompson.

[6] Mafinejad, Mahboobeh., et al. Medical Students Attitudes towards early clinical exposure in Iran. International Journal of Medical Education.2016; 7:195-199 ISSN:2042-6372. DOI:10.5116/ijme.5749.78af

[7] MotilalTayadeC. ,NoorinBhimani.,Nandkumar

[8] Natawidjaya, Rochman. 2009. KonselingKelompok, KonsepDasardanPendekatan. Bandung: Rizqi P ress 
[9] Rawekar Alka., ArunitaJagzape.,TriptiSrivastav., ShashankGotarkar. 2016. Skill Learning Through Early Clinical Exposure: An Experience of Indian Medical School.Journal of Clinical and Diagnostic Research. Jan, Vol- 10(1): JC01-JC04

[10] Sawant and ShaheenRizvi. 2015. Importance of Early Clinical Exposure in Learning Anatomy

[11] Scholars Journal of Applied Medical Sciences (SJAMS) ; 3(2):10351038

[12] Sutanti, Tri. 2014. Pelaksanaan Layanan Konseling Kelompok Untuk Anak Cerdas Istimewa di SMA Negeri Kota Yogyakarta. Jurnal Gusjigang, Volume 1, no. 1 Juni 2015. hal 110-124. ISSN 2460-1187

[13] Suwarjo, S., I. B. Maryatun, and N. Kusumadewi. 2012. Penerapan student centered approach padapembelajarantamankanakkanakkelompok B (studikasus di sekolahlaboratoriumrumahcitta). Jurna IPendidikan Anak 1 (1).

[14] Tayade, M. C. 2015. Fetal alcohol spectrum disorders (FASD) and slow wave sleep. Pravara Medical Review 7 (4):4-5. 